\title{
Penerapan Algoritma Nearest Neighbor dan CBR pada Expert System Penyimpangan Perilaku Seksual
}

\author{
Salamun \\ Teknik Informatika Universitas Abdurrab \\ J1. Riau Ujung No 73, Pekanbaru-Riau \\ salamun@univrab.ac.id
}

\begin{abstract}
In building a computerized system especially in expert system, it is desperately needed an innovation result which result better. In this case it discusses the algorithm that uses the closest neighbor method with the Case-Based Reasoning (CBR) method, where the neighbor's closest algorithm serves to classify the problem in the presence of CBR serves as a tool to solve problems already classified with the nearest neighbor algorithm. CBR is a method that has a unique way of working, that is case-based criminal, where the results of the cases that have been analyzed in getting from a case that has happened before. In a sense, this method is a method that can be taken according to its prior experience. In this case it discusses sexual behavior that deviates to LGBT especially men, where the results of this study produce the kinds of irregularities and levels of irregularities committed by the LGBT community, this expert system can help psychologists to find and analyze existing cases as well as providing advice and input to those who have deviations from sexual behavior.
\end{abstract}

Keywords: Nearest Neighbor, CBR, Expert System

Abstrak- Dalam membangun sebuah sistem yang terkomputerisasi khususnya sistem pakar, sangat dibutuhkan sebuah inovasi-inovasi demi mendapatkan hasil yang lebih baik. Dalam kasus ini membahas tentang penerapan algoritma nearest neighbor dan metode Case-Based Reasoning (CBR), dimana algoritma nearest neighbor berfungsi untuk mengklasifikasikan masalah yang ada sedangkan CBR berfungsi sebagai alat untuk penyelesaian masalah yang sudah diklasifikasikan dengan algoritma nearest neighbor. CBR merupakan metode yang memiliki cara kerja yang unik, yaitu penalaran berbasis kasus, dimana hasil dari kasus yang sudah di analisa didapatkan dari kasus yang sudah pernah terjadi sebelumnya. Dalam artian, metode ini merupakan metode yang dapat mengambil kesimpulan berdasarkan pengalaman sebelumnya. Dalam kasus ini membahas tentang perilaku seksual yang menyimpang pada kaum LGBT khususnya kaum laki-laki, dimana hasil dari penelitian ini didapatkan berupa jenis-jenis penyimpangan dan tingkat penyimpangan yang dilakukan oleh komunitas LGBT, sistem pakar ini dapat membantu psikolog untuk mencari dan menganalisa kasus yang ada serta memberikan saran dan masukan kepada penderita yang memiliki penyimpangan perilaku seksual.

Kata kunci : Nearest Neighbor, CBR, Sistem Pakar

\section{PENDAHULUAN}

Perilaku seksual yang menyimpang merupakan sebuah penyakit kelainan yang tidak terlihat oleh kasat mata pada masyarakat umum. Dengan kemajuan teknologi pada saat ini yang serba terkomputerisasi salah satu dari perkembangan teknologi adalah kecerdasan buatan yaitu Sistem Pakar yang merupakan teknologi komputer yang mampu memberikan kemudahan untuk kalangan awam.

Case-Based Reasoning (CBR) merupakan sebuah metode untuk memecahkan masalah baru dengan mencari solusi kasus-kasus lama yang mirip kemudian menggunakan solusi kasus lama tadi untuk menyelesaikan masalah baru [2].

Case-Based Reasoning melakukan proses mengingat penyelesaian masalah sebelumnya. Kemudian ketika ada permasalahan baru, Case-Based Reasoning melakukan perbandingan antara karakteristik permasalahan baru dengan permasalahan yang pernah diselesaikan sebelumnya [4].

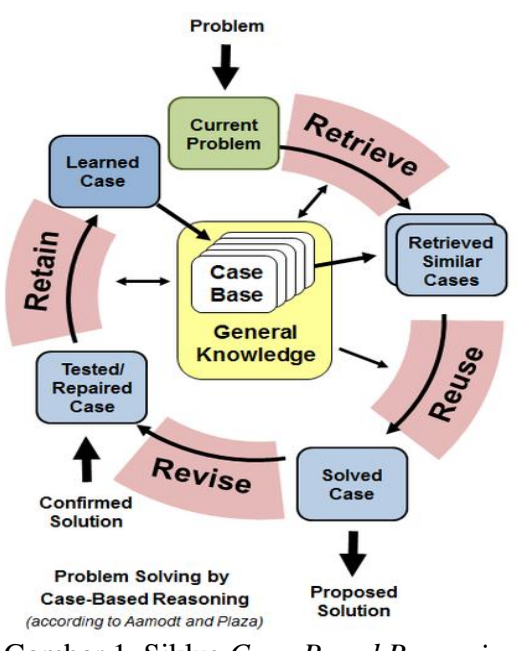

Gambar 1. Siklus Case-Based Reasoning

Secara umum metode ini terdiri dari 4 langkah yaitu[11]: 1. Retrieve

Pada proses ini adalah proses pengenalan masalah, yaitu dengan mengidentifikasi masalah yang baru. 


\section{Reuse}

Dalam proses Reuse, sistem akan melakukan pencarian masalah terdahulu pada database melalui identifikasi masalah baru. Kemudian menggunakan kembali informasi permasalahan terdahulu tersebut yang memiliki kesamaan untuk menyelesaikan permasalahan yang baru.

3. Retain

Pada proses terakhir ini, sistem akan menyimpan permasalahan baru ke dalam knowledge-based untuk menyelesaikan permasalahan yang akan datang.

4. Revise

Pada proses ini, informasi akan dievaluasi kembali untuk mengatasi masalah yang terjadi pada permasalahan baru. Kemudian sistem akan mengeluarkan solusi masalah baru.

Tujuan utama dari pengambilan kasus adalah untuk mencari kemiripan dalam setiap kasus dimana akan dilakukan penalaran untuk mencari solusi-solusi yang diinginkan.

\section{A. Algoritma Nearest Neighbor}

Algoritma nearest neighbor merupakan pendekatan untuk mencari kasus dengan kedekatan antara kasus baru dengan kasus lama, yaitu berdasarkan pada kecocokan bobot sejumlah fitur yang ada. Metode ini mencari jarak terhadap tujuan dari data yang telah disimpan sebelumnya. Setelah didapatkan jaraknya kemudian dicari jarak terdekat. Jarak terdekat tersebut yang digunakan untuk mencari identitas tujuan [3].

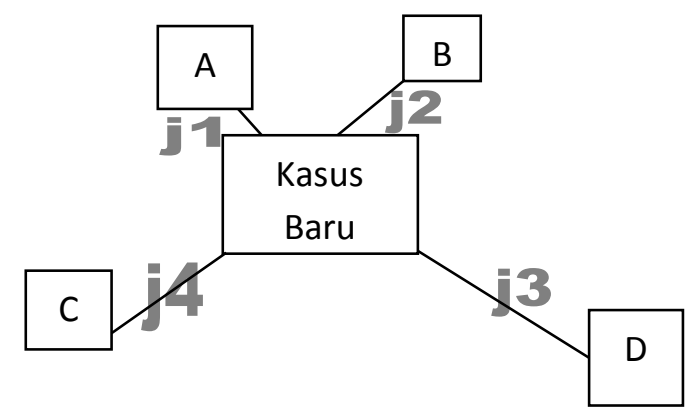

Gambar 2. Ilustrasi Algoritma Nearest Neighbor

Dari gambar ilustrasi di atas dapat dijelaskan bahwa ada terdapat 4 pasien lama yang disimbolkan oleh (A, B, C dan D). Ketika ada pasien baru maka yang diambil solusi adalah solusi dari kasus pasien lama yang memiliki kedekatan terbesar. Misal $j l$ adalah jarak antara pasien baru dengan pasien $A, j 2$ adalah jarak antara pasien baru dengan pasien $B, j 3$ adalah jarak antara pasien baru dengan pasien $C, j 4$ adalah jarak antara pasien baru dengan pasien $D$. Dari ilustrasi gambar terlihat bahwa $j 1$ yang paling terdekat dengan kasus baru. Dengan demikian maka solusi dari kasus pasien $A$ yang akan digunakan sebagai solusi dari pasien baru tersebut.
Adapun rumus yang digunakan dalam perhitungan kedekatan (similarity) adalah sebagai berikut (17) :

$$
\begin{aligned}
& \text { Similarity (problem,case) }=\frac{\mathrm{s} 1 * \mathrm{w} 1+\mathrm{s} 2 * \mathrm{w} 2+\ldots \ldots+\mathrm{s}^{*}{ }^{\mathrm{w} 11}}{\mathrm{w} 1+\mathrm{w} 2+\ldots \ldots+\mathrm{w} 1} \\
& \mathrm{~S} \quad=\text { similarity ( nilai kemiripan) } \\
& \mathrm{W} \quad=\text { weight ( bobot yang diberikan) }
\end{aligned}
$$

\section{B. Homoseksual}

Banyak ahli dari berbagai disiplin ilmu berusaha untuk menjelaskan mengapa homoseksualitas dalam diri seseorang dapat terbentuk. Namun di antara banyak hipotesa dan teori yang diajukan hingga saat ini belum ada satu pun teori yang bisa menjawab secara akurat mengapa seorang individu bisa menjadi homoseks[7].

Homoseksualitas didefinisikan sebagai orientasi kebutuhan seksual, keinginan, atau responsif terhadap orang lain jenis kelamin yang sama [5]. Istilah homo diambil dari bahasa Yunani yang artinya sama. Istilah ini pertama kali diperkenalkan di Eropa menjelang Akhir abad-19. Untuk itu lebih tepatnya, jika penderita homoseksual tersebut laki - laki, sebutannya gay sedangkan untuk wanita disebut lesbian [6].

\section{METODE PENELITIAN}

Metode penelitian adalah gambaran atau langkahlangkah yang akan dilaksanakan dalam melakukan penelitian ini bertujuan untuk supaya penelitian dapat dilakukan dengan terstruktur. Langkah yang akan dilakukan harus mencakup mulai dari mempelajari sampai dengan adanya suatu sistem yang dapat memberikan penyelesaian masalah yang sedang diteliti. Dalam perancangan Sistem Pakar ini yaitu dengan melakukan kerangka kerja yang terdiri dari beberapa tahapan.

Uraian langkah kerja yaitu dapat dilihat pada gambar 3, yaitu sebagai berikut :

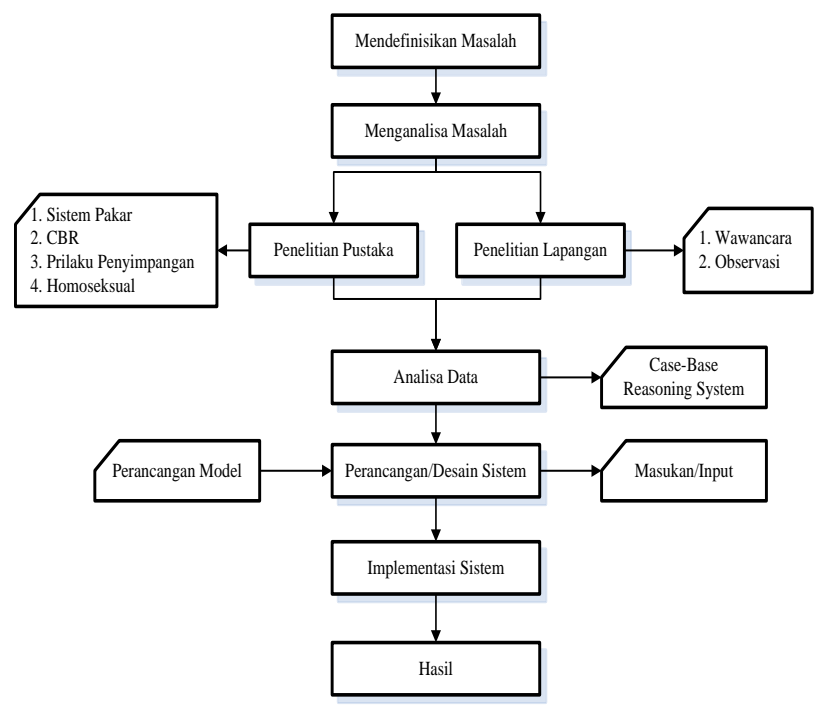

Gambar 3. Langkah Kerja Penelitian 


\section{HASIL DAN PEMBAHASAN}

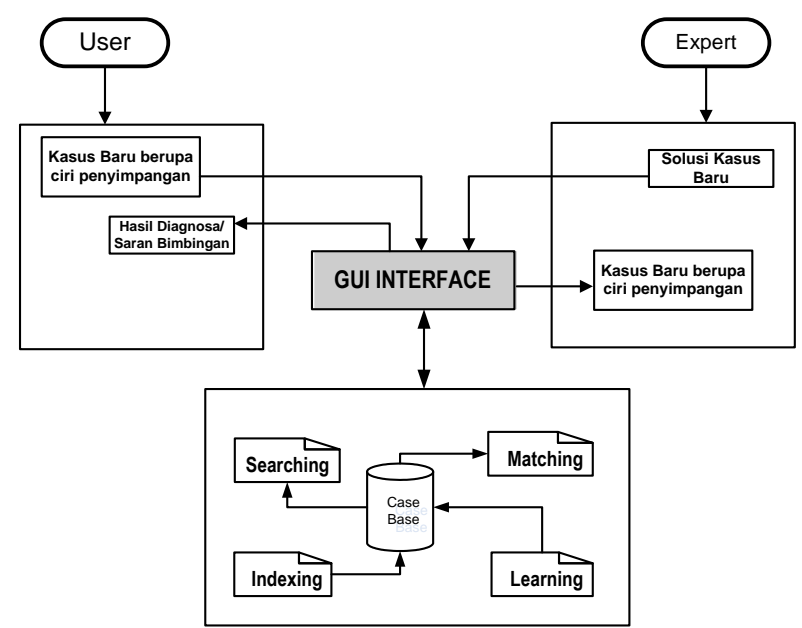

Gambar 4. Arsitektur Case-Based Reasoning

Sistem Case-Based Reasoning yang dipakai mempunyai inputan berupa spesifikasi masalah dari ciriciri jenis penyimpangan yang didapat dari hasil jawaban kuisoner antara sistem dengan user, kemudian akan melakukan penalaran terhadap masalah tersebut dan mengeluarkan jawaban kepada user secara otomatis. Berikut ini adalah gambaran arsitektur sistem yang akan dipakai, yaitu : Gambar 4. memperlihatkan Arsitektur Case-Based Reasoning di mana user memberikan data inputan kepada sistem berupa ciri penyimpangan dan masuk kedalam aplikasi Sistem Pakar yang telah dirancang dan masuk ke proses case-based. Dalam proses case-based, Kasus Baru akan dilakukan proses pencarian kasus yang tersimpan case memory, kemudian proses pencocokan kasus baru dengan kasus di case memory, kemudian membaca kemiripan kasus setelah dilakukan pencocokkan untuk mencari kemiripan, nilai kemiripan yaitu proses mengambilan nilai kemiripan tertinggi setelah dilakukan proses pencocokkan. Dalam proses case-based telah dilakukan dan didapat solusi. Solusi akan keluar dari proses case-based dan melewati Aplikasi Sistem Pakar. Setelah itu maka didapatlah output berupa solusi baru. Ketika sistem tidak menemukan kecocokan kasus antara kasus baru dan kasus lama maka sistem akan menyimpan data kasus yang belum memiliki solusi di mana kasus ini nantinya akan diperbaiki atau dievaluasi oleh pakar untuk mendapatkan solusi yang akan diinputkan ke dalam sistem.

Pada gambar 5, adalah proses Case-Based Reasoning yang menunjukkan proses kerja Case-Based Reasoning dalam mencari kemiripan dengan mencocokkan kasus baru yang ada dengan kasus lama yang telah tersimpan di dalam case memory.

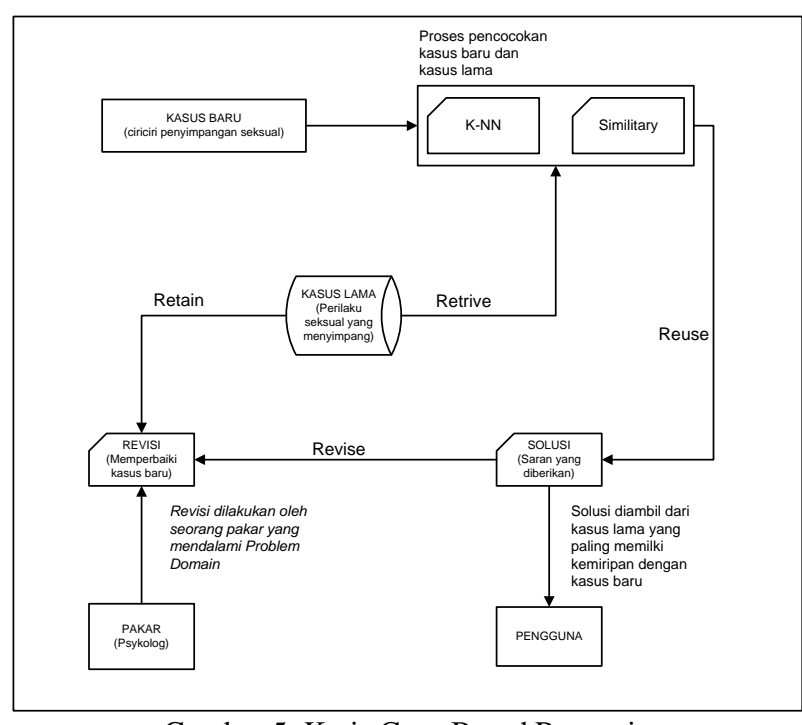

Gambar 5. Kerja Case-Based Reasoning

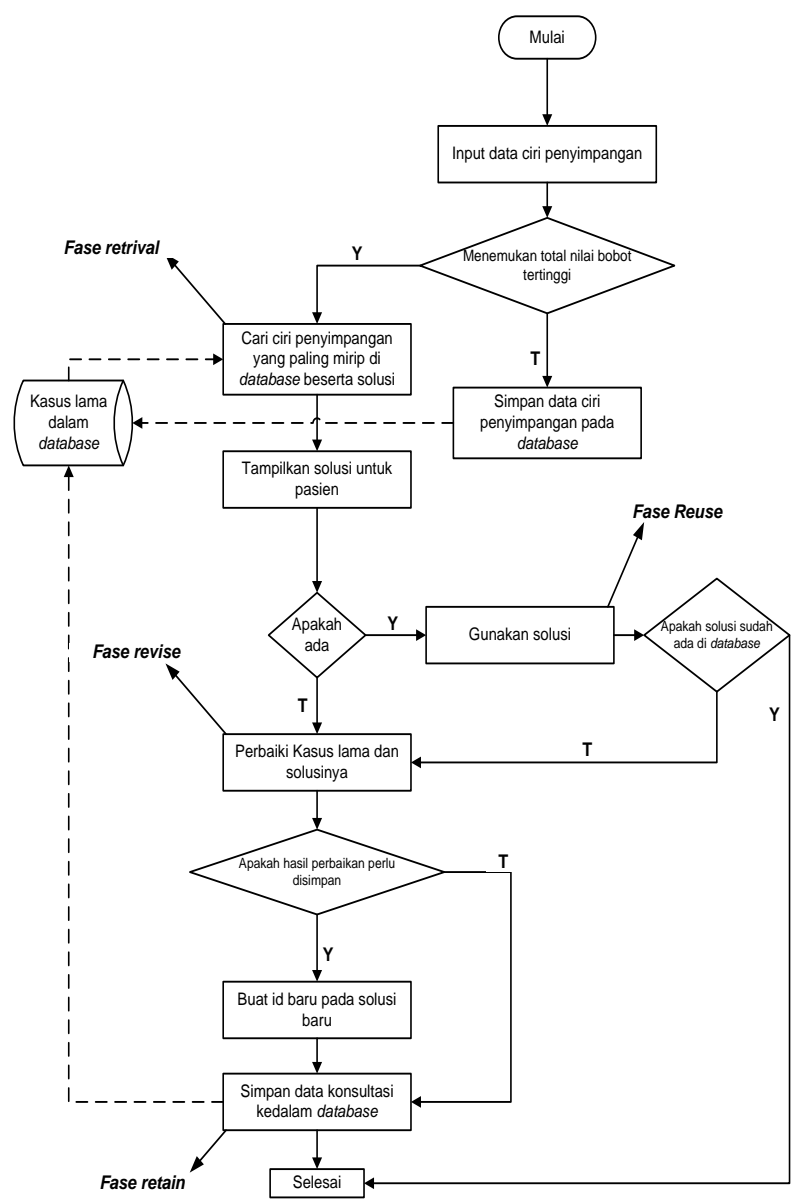

Gambar 6. Flowchart Sistem Pakar Case-Based Reasoning

\section{A. Perhitungan Kasus Menggunakan Rumus Nearest Neighbour Retrieval}

Pada tahap ini akan dilakukan perhitungan kasus di mana dalam perhitungan kasus baru dengan kasus lama ini bertujuan untuk mencari kemiripan yaitu menggunakan menggunakan proses pembobotan menggunakan rumus Nearest Neighbour Retrieval. 
Perhitungan kasus I:

\begin{tabular}{|l|l|l|}
\hline \multicolumn{1}{|r|}{ Kasus Baru $(\mathrm{X})$} & & Kasus Lama (K1) \\
\cline { 1 - 1 } - C9 & & $-\mathrm{C} 1$ \\
$-\mathrm{C} 10$ & -Tidak Sama & $-\mathrm{C} 2$ \\
$-\mathrm{C} 11$ & $-\mathrm{C} 3$ \\
$-\mathrm{C} 12$ & $-\mathrm{C} 4$ \\
\hline
\end{tabular}

Gambar 7. Perhitungan Kasus I

Similitary (X, K1)

$$
\begin{aligned}
& =\frac{(0 * 0)+(0 * 0)+(0 * 0)+(0 * 0)}{2+2+4+2} \\
& =\frac{0+0+0+0}{10}=\frac{0}{10} \\
& =\frac{0}{10} \\
& =0
\end{aligned}
$$

Pada perhitungan di atas menjelaskan mengenai perhitungan mencari kemiripan suatu kasus baru dengan kasus lama menggunakan rumus Nearest Neighbour Retrieval berdasarkan ciri-ciri pada seperti yang dijelaskan pada gambar 7. Dalam contoh kasus di atas dapat dilihat tidak ada ciri-ciri yang memiliki kemiripan

\begin{tabular}{|c|c|c|}
\hline Kasus Baru (X) & & Kasus Lama (K2) \\
\hline $\begin{array}{l}-\mathrm{C} 5 \\
-\mathrm{C} 6 \\
-\mathrm{C} 7 \\
-\mathrm{C} 8\end{array}$ & -Tidak Sama- & $\begin{array}{l}-\mathrm{C} 13 \\
-\mathrm{C} 14 \\
-\mathrm{C} 15 \\
-\mathrm{C} 16\end{array}$ \\
\hline
\end{tabular}
kasus baru dengan kasus lama. Melalui perhitungan di atas didapat hasil 0 pada perhitungan kasus pertama.

Perhitungan kasus II:

Gambar 8. Perhitungan Kasus II

Similarity (X, K2)

$$
\begin{aligned}
& =\frac{(0 * 0)+(0 * 0)+(0 * 0)+(0 * 0)}{2+1+2+4} \\
& =\frac{0+0+0+0}{9}=\frac{0}{9} \\
& =0
\end{aligned}
$$

Pada perhitungan kasus yang kedua di atas didapat nilai kemiripan dimana ciri-ciri pada kasus baru yang diberikan tidak memiliki kecocokan dengan kasus lama dimana kode ciri pada kasus baru yaitu C5, C6, C7 dan C8 dan didapat hasil nilai kemiripan melalui perhitungan Nearest Neighbour Retrieval sebesar 0.
Perhitungan kasus III:

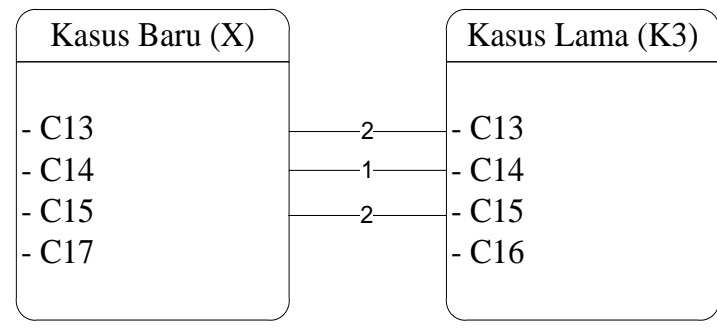

Gambar 9. Perhitungan Kasus III

Similarity $(\mathrm{X}, \mathrm{K} 3)$

$$
\begin{aligned}
& =\frac{(2 * 1)+(1 * 1)+(2 * 1)+(0 * 0)}{2+1+2+4} \\
& =\frac{2+1+2+0}{9}=\frac{5}{9} \\
& =0,56
\end{aligned}
$$

Pada perhitungan kasus yang ketiga di atas didapat nilai kemiripan di mana kode ciri-ciri pada kasus baru yang diberikan memiliki kecocokan dengan kasus lama kode ciri yaitu $\mathrm{C} 13, \mathrm{C} 14$, dan $\mathrm{C} 15$ dan didapat dari hasil

\begin{tabular}{|c|c|}
\hline Kasus Baru (X) & Kasus Lama (K3) \\
\hline$-\mathrm{C} 13$ & $-\mathrm{C} 13$ \\
\hline - C14 & $-\mathrm{C} 14$ \\
\hline$-\mathrm{C} 15$ & $-\mathrm{C} 15$ \\
\hline$-\mathrm{C} 17$ & $-\mathrm{C} 16$ \\
\hline
\end{tabular}
perhitungan yang sudah dilakukan maka didapat nilai kemiripan melalui perhitungan Nearest Neighbour Retrieval sebesar 0,56.

\section{Reuse}

Pada proses reuse, sistem menggunakan informasi permasalahan sebelumnya berdasarkan bobot kemiripan yang paling relevan ke dalam kasus yang baru di mana memiliki kesamaan untuk menyelesaikan permasalahan yang baru.

Similarity $(\mathrm{X}, \mathrm{K} 3)$

$$
\begin{aligned}
& =\frac{(2 * 1)+(1 * 1)+(2 * 1)+(0 * 1)}{2+1+2+4} \\
& =\frac{2+1+2+0}{9}=\frac{5}{9} \\
& =0,56
\end{aligned}
$$

Perhitungan di atas dimana kasus yang memiliki nilai kemiripan paling rendah adalah kasus dengan kode K1 dan K2 yaitu memiliki nilai kemiripan kasus sebesar 0 dan yang paling tinggi adalah kasus dengan kode K3 yaitu memiliki nilai kemiripan kasus sebesar 0,56. Pada proses reuse, solusi yang diberikan adalah solusi dengan nilai kemiripan kasus lama dengan kasus baru yang paling 
tinggi, dalam contoh kasus ini adalah kasus K3. Hasil perhitungan dengan nilai menunjukkan tingkat kepercayaan $56 \%$ jadi solusi kasus K3 adalah yang direkomendasikan kepada user yaitu solusi yang terdapat pada kasus lama dimana sudah dilakukan pencocokan kasus dan memiliki nilai yang dapat direkomendasikan. Pada perhitungan di atas dapat dilihat bahwa hasil perhitungan manual dan program cocok, yaitu menghasilkan output jenis perilaku seksual dan saran yang akan diberikan.

Tabel 1. Hasil Kriteria Kemiripan Setiap Kasus Dengan Kasus

\begin{tabular}{lll}
\multicolumn{2}{c}{ Baru } \\
\hline & Basis Kasus & Nilai Kemiripan \\
\hline K1 & 0 \\
K2 & 0 \\
\hline K3 & 0,56 \\
\hline
\end{tabular}

Dari tabel di atas dapat dijelaskan :

Setelah melakukan pencarian kemiripan kasus baru dengan setiap kasus lama yang telah tersimpan di case memory dengan proses Case-Based Reasoning menggunakan k-nearest neighbor didapatlah hasil kriteria kemiripan setiap kasus dengan kasus baru pada tabel 1 . Pada tabel 1 dapat dilihat bahwa K3 memperoleh nilai kemiripan lebih tinggi sebesar 0,56. Untuk K1 dan K2 nilai kemiripannya sebesar 0 , karena $\mathrm{K} 1$ dan $\mathrm{K} 2$ tidak mempunyai ciri-ciri perilaku penyimpangan yang mirip dengan kasus baru.

Oleh karena itu kasus K3 akan dipilih menjadi solusi yang disarankan untuk kasus baru tersebut. Karena memiliki kriteria kemiripan paling tinggi yaitu sebesar $55 \%$ atau 0,56 seperti pada tabel 1. Dengan kata lain, kasus baru tersebut kemungkinan jenis penyimpangan yang dihasilkan yaitu homoseksual situasional.

Saran yang diberikan adalah:

a. Hindari situasi atau orang yang membuat kecenderungan homoseks anda timbul karena biasanya anda akan kembali mempraktekkan heteroseksual sesudah keluar dari situasi tersebut.

b. Terus yakini bahwa anda normal karena awalnya anda suka dengan lawan jenis.

c. Beri tahu orang yang dipercaya tentang perubahan kecenderungan rasa suka yang anda rasakan sehingga dapat membantu atau mendukung anda untuk berubah.

d. Rasa nyaman ataupun bahagia yang anda dapatkan sekarang dari sesama jenis merupakan hal semu sehingga jangan terlalu terlena dengan hal tersebut.

e. Minta bantuan kepada psikolog untuk mengubah cara berpikir anda ataupun memberikan terapi.

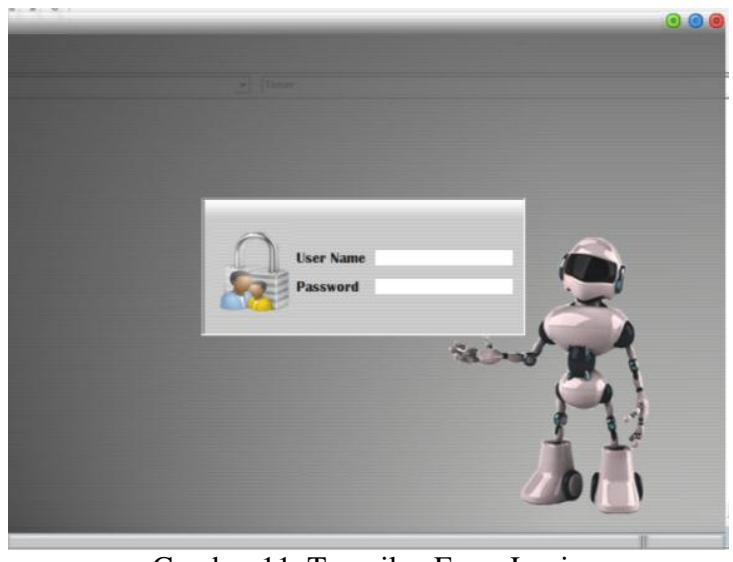

Gambar 11. Tampilan Form Login

1. Setelah melakukan login maka akan dihadapkan dengan tampilan menu utama dimana pada tampilan menu utama ini terdapat beberapa menu yaitu terdiri dari menu kuisioner, menu input gejala, menu hasil diagnosa, menu perbaikan kasus, menu log out dan menu exit. Menu exit disini berfungsi untuk menutup aplikasi sedangkan menu log out berfungsi untuk mengarahkan pengguna kepada form login kembali. Untuk menu utama dapat dilihat pada gambar 12.

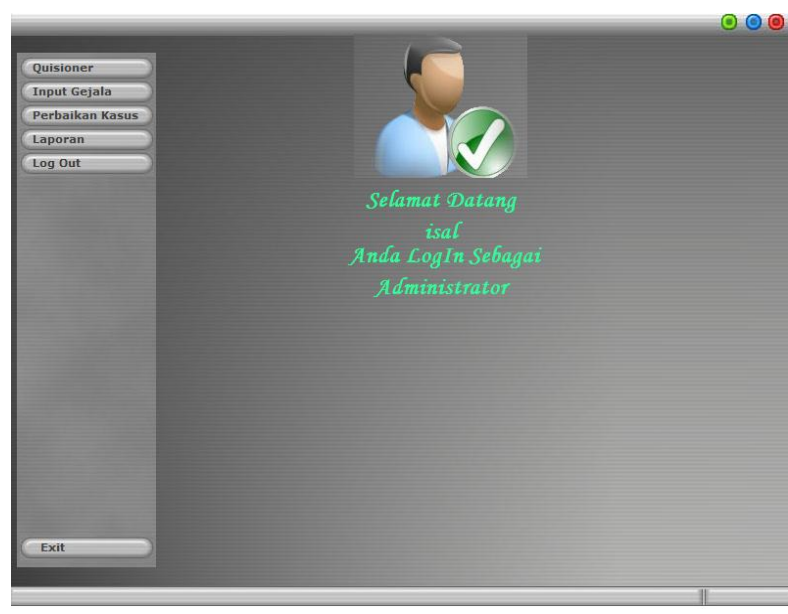

Gambar 12. Tampilan Menu Utama

2. Pada menu utama dapat dilihat ada beberapa pilihan menu yang pertama menu kuisioner, menu ini berfungsi untuk menampilkan form kuisioner atau konsultasi untuk mengisi jawaban dari pernyataan-pernyataan yang diberikan kepada pasien dimana jawaban yang diharapkan hanya dua yaitu ya dan tidak saja ketika semua pernyataan atau konsultasi telah selesai dilaksanakan maka user akan melakukan pemrosesan data yang telah diisi oleh pasien, untuk lebih jelasnya dapat dilihat pada gambar 13 . 


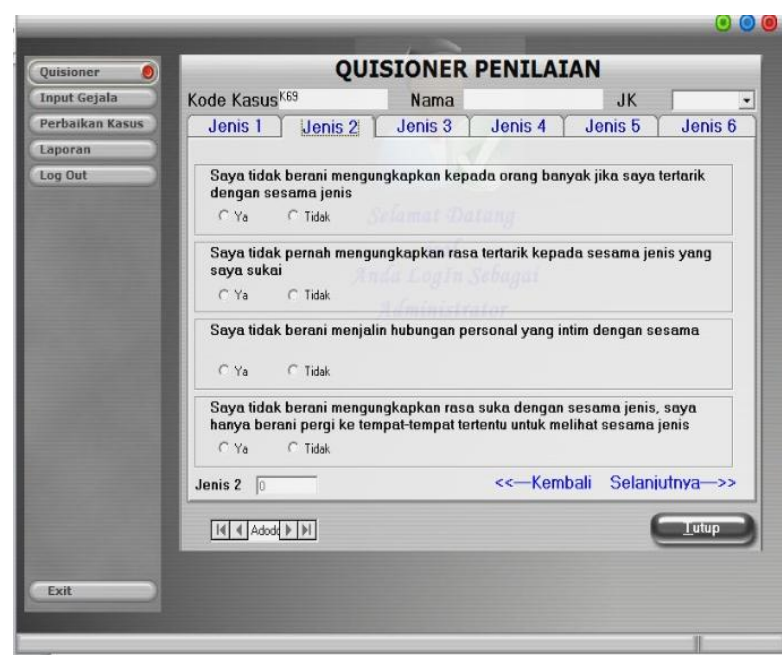

Gambar 13. Tampilan Menu Kuisioner

Ketika semua pernyataan atau konsultasi telah selesai dilaksanakan maka user akan melakukan pemrosesan data yang telah diisi oleh pasien, untuk lebih jelasnya dapat dilihat pada gambar 14 .

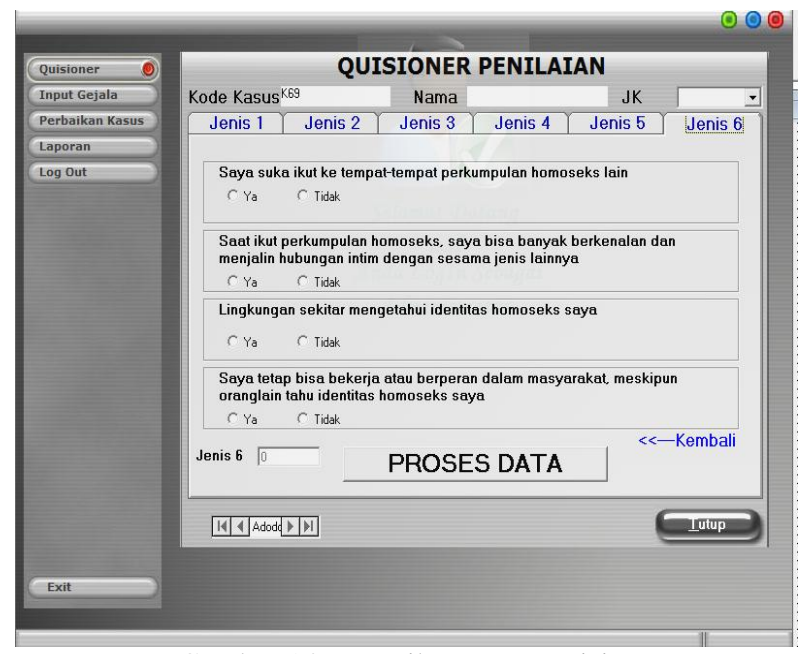

Gambar 14. Tampilan Menu Kuisioner

3. Pada saat user menekan tombol proses data maka sistem secara otomatis akan memproses data CaseBased Reasoning dan menampilkan hasil dari konsultasi yang telah dilakukan. Pada Form ini user dapat melihat apakah gejala-gejala yang dipilih oleh pasien sudah ada solusinya atau tidak. Untuk lebih jelasnya dapat dilihat pada gambar 15 .

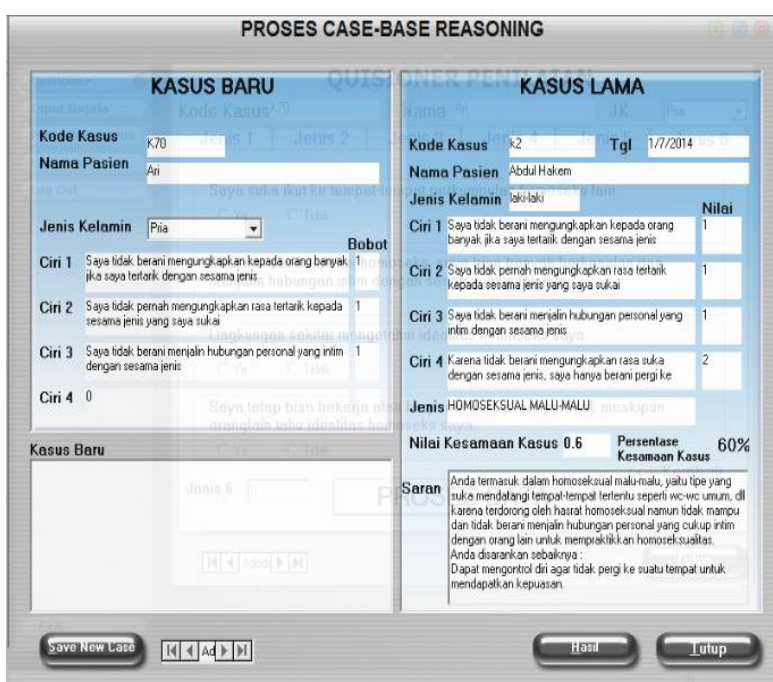

Gambar 15. Tampilan Case-Based Reasoning

Pada gambar 15 di atas dapat dilihat bahwa kasus yang baru sudah memiliki solusi dimana untuk menentukan solusi tersebut menggunakan metode CaseBased Reasoning yaitu pencocokan kasus baru dengan kasus lama dengan memberikan bobot pada setiap pernyataan, ketika kasus baru memiliki kesamaan dengan kasus lama maka sistem akan menampilakan hasil diagnosa lengkap dengan bobot kesamaan kasus dan saran yang akan diberikan.

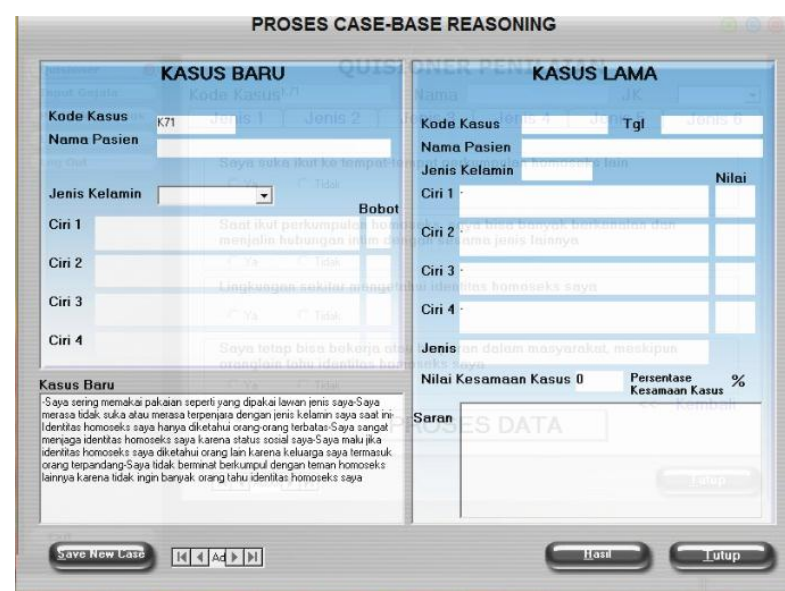

Gambar 16. Tampilan Ketika Kasus Tidak Ada Solusi

Akan tetapi ketika sistem menemukan kasus baru yang tidak memiliki kecocokan dengan kasus lama maka sistem akan menyimpan kasus baru tersebut ke dalam database di mana nantinya akan diperbaiki oleh pakar pada form perbaikan pengetahuan. Untuk lebih jelasnya dapat dilihat pada gambar 16.

4. Pada saat solusi dari kasus baru tidak ditemukan di form Case-Based Reasoning maka sistem akan menyimpan kasus baru tersebut ke dalam database untuk kemudian akan diperbaiki oleh pakar. Pada form perbaikan kasus ini pakar dapat melihat langsung kasus baru yang belum memiliki solusi dan pakar juga dapat mengevaluasi kasus lama apa 
bila ada pengetahuan yang ingin diperbaiki. Untuk lebih jelasnya dapat dilihat pada gambar 17 .

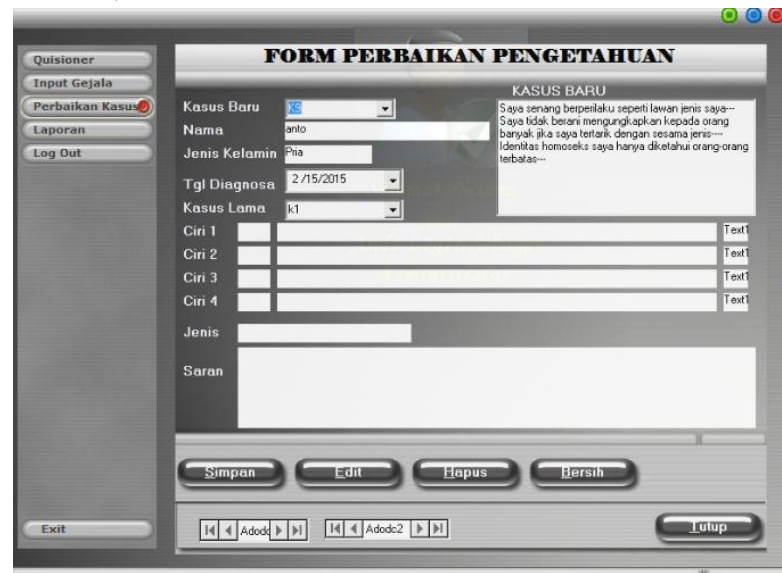

Gambar 17. Tampilan Perbaikan Kasus

Gambar 18 merupakan form perbaikan pengetahuan di mana seorang pakar dapat melakukan perbaikan pengetahuan apabila pada pengetahuan yang sudah ada sebelumnya pada database mengalami perubahan maka disediakan form perbaikan pengetahuan yang nantinya pengetahuan yang telah diperbaiki akan disimpan kembali kedalam database.

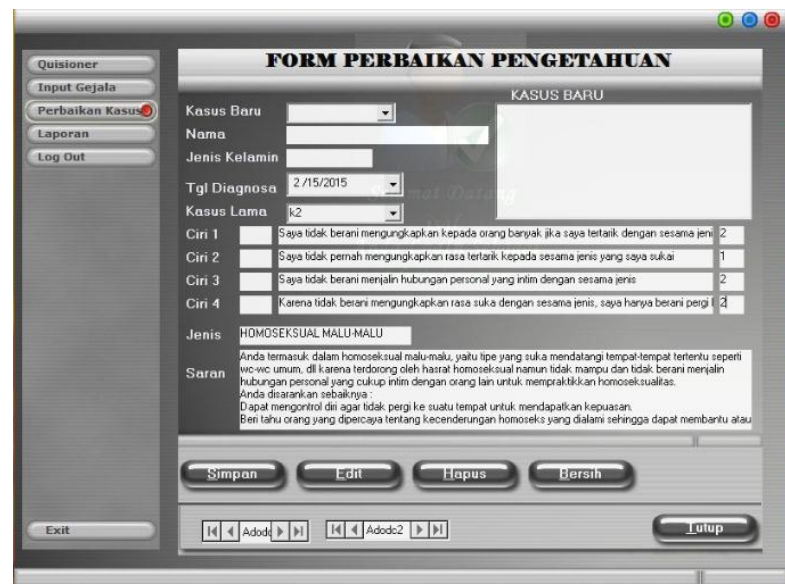

Gambar 18. Tampilan Perbaikan Kasus

5. Selanjutnya adalah proses yang terakhir yaitu laporan hasil konsultasi dimana form ini berfungsi untuk menampilkan hasil konsultasi ketika kasus baru sudah didapatkan solusi yang tepat dari proses Case-Based Reasoning. Form ini akan menyimpan hasil konsultasi ke dalam database dan sewaktu-waktu apabila data tersebut diperlukan kembali maka dapat dilihat atau dicetak kembali. Untuk lebih jelasnya dapat dilihat pada gambar 18 .

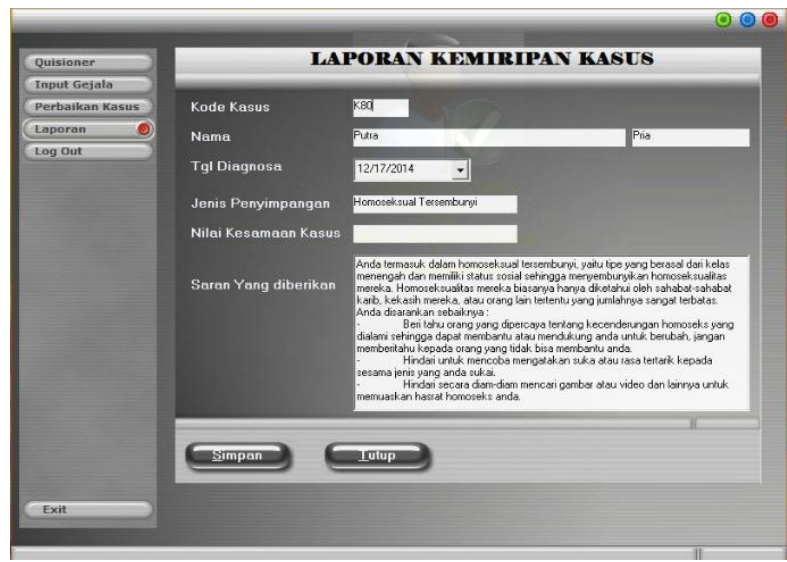

Gambar 18. Tampilan Hasil Diagnosa

Pada gambar 18 merupakan tampilan hasil diagnosa dimana hasil tersebut didapat setelah pasien mengisi seluruh pernyataan-pernyataan yang terdapat pada kuisioner. Hasil yang diberikan yaitu berupa jenis penyimpangan perilaku seksual dan nilai kemiripan kasus baru dan kasus lama serta pasien juga diberikan saran dimana saran ini merupakan anjuran untuk pasien agar dapat mengurangi perilaku penyimpangan yang sedang terjadi.

\section{KESIMPULAN}

Dari penelitian yang telah dilakukan dapat diambil kesimpulan yaitu adalah sebagai berikut :

1. Sistem yang menggunakan metode Case-Based Reasoning dapat memberikan solusi atau bimbingan yang paling tepat kepada seseorang yang memiliki perilaku seksual yang menyimpang baik itu laki-laki maupun perempuan.

2. Dalam metode Case-Based Reasoning menggunakan algoritma Nearest Neighbor yaitu dalam pencocokan kasus berdasarkan pembobotan pada setiap pernyataan dimana pada perhitungan pembobotan menggunakan rumus Nearest Neighbor.

Pernyataan-pernyataan yang diberikan kepada pasien merupakan ciri-ciri dari perilaku seksual yang menyimpang dimana ciri-ciri tersebut merupakan probem case dimana nantinya akan menghasilkan sebuah solusi untuk diberikan kepada pasien yang disebut solution space. Pada setiap ciri yang dipilih oleh pasien itu memiliki bobot yang berbeda dimana ciri yang sangat penting memiliki bobot 4 (empat), ciri penting memiliki bobot 2 (dua), sedangkan ciri yang sedang memiliki bobot 1 (satu). 


\section{REFERENSI}

[1] Abdul, S. S. (2013)." Sistem Pakar Diagnosa Penyakit Dan Hama Tanaman Padi." Pelita Informatika Budi Darma. 3. 8.

[2] Bimmo, S. W, et al. (2014)." Analisis dan Implementasi Sistem Pendiagnosis Penyakit Tuberculosis Menggunakan Metode CaseBased Reasoning." Prosiding Seminar Nasional Aplikasi Teknologi dan Informasi (SNATI). Universitas Islam Indonesia, Yogyakarta. Teknik Informatika.

[3] Chusnul, I. dan Aries, D. I. (2013). “ Penerapan Case Based Reasoning Dengan Algoritmanearest Neighbor Untuk Analisis Pemberian Kredit Dilembaga Pembiayaan.” Jurnal Manajemen Informatika.2. 11-21.

[4] Hanisah, A (2014). " Computer Fault Diagnosis System Using Case - Based Reasoning Approach. "International Journal of Latest Research in Science and Technology. 3. 4.

[5] Hasan, Hafiedh. 2009. “ Pengaruh Pendidikan Seks Terhadap Perilaku Seksual Siswa Di Man Pakem Yogyakarta ". Yogyakarta: Universitas Islam Indonesia. 65-68

[6] Okdinata. 2009." Religiusitas Kaum Homoseks Studi Kasus Tentang Dinamika Psykologis Keberagamaan Kaum Gay Musilim Di Yogyakarta ."Universitas Negeri Sunan Kalijaga Yogyakarta .: Skripsi Starat Satu.

[7] Kartono, K 2009." Psikologi Abnormal dan Abnormalitas Seksual.” Bandung.: CV. Mandar Maju. 102-110

[8] Irlando, M. P, et al. (2012).” Penerapan Case-Based Reasoning pada Sistem Cerdas untuk Pendeteksian dan Penanganan Dini Penyakit Sapi." JURNAL TEKNIK ITS. 1. A-352.

[9] Mohamad, F. M. M, et al. (2011)." Faster Case Retrieval Using Hash Indexing Technique." International Journal of Artificial Intelligence and Expert Systems (IJAE).2. 82.

[10] Mwanawina, I. (2012)." Homosexual Rights and the Law: A South African Constitutional Metamorphosis." International Journal of Humanities and Social Science.2. 50.

[11] Murien, N. (2012)." Rancangan Case-Based Reasoning Menggunakan Sorenson Coefficient." JURNAL INFORMATIKA. 6. 612-613.

[12] Minarni dan Rahmad, H. (2013).” Rancang Bangun Aplikasi Sistem Pakar Untuk Kerusakan Komputer Dengan Metode Backward Chaining." Jurnal TEKNOIF. 1. 27.

[13] T. Sutojo, et al (2011). “ Kecerdasan Buatan.” Ed 1. Yogyakarta.: Andi. 163-171

[14] Reny, R. dan Ardi, P. (2013). “ Implementasi Case Base Reasoning Pada Sistem Pakar Dalam Menentukan Jenis Gangguan Kejiwaan. “Jurnal Sarjana Teknik Informatika. 1. 110 .

[15] Souad, G, et al. (2012). “ Combining Case and Rule Based Reasoning for the Diagnosis and Therapy of Chronic Obstructive Pulmonary Disease." International Journal of Hybrid Information Technology. 5. 146.

[16] Sae-Hyun Ji. et al. (2010). "Similarity Measurement methods of case -based reasoning for conceptual cost estimation." Proceedings of the internatonal conference on computing in civil and building engineering.1.

[17] Surjeet, D. et al.(2011)." Case Retrieval Optimization of Casebased reasoning through Knowledge-Intensive Similarity Measures." International Journal of Computer Applications .34. 12.

[18] Tomas, O, et al. (2014)." Case-Based Reasoning for Explaining Probabilistic Machine Learning." International Journal of Computer Science \& Information Technology (IJCSIT).6. 87. 